\title{
Cardiovascular benefits of exercise
}

This article was published in the following Dove Press journal:

International Journal of General Medicine

21 June 2012

Number of times this article has been viewed

\section{Shashi K Agarwal}

Agarwal Health Center, East Orange, NJ, USA
Correspondence: Shashi K Agarwal Agarwal Health Center, 198 Central Ave, East Orange,

NJ 07018, USA

Tel +9736761234

Fax +9736760009

Email skagarwal@pol.net
Abstract: Regular physical activity during leisure time has been shown to be associated with better health outcomes. The American Heart Association, the Centers for Disease Control and Prevention and the American College of Sports Medicine all recommend regular physical activity of moderate intensity for the prevention and complementary treatment of several diseases. The therapeutic role of exercise in maintaining good health and treating diseases is not new. The benefits of physical activity date back to Susruta, a $600 \mathrm{BC}$ physician in India, who prescribed exercise to patients. Hippocrates (460-377 BC) wrote "in order to remain healthy, the entire day should be devoted exclusively to ways and means of increasing one's strength and staying healthy, and the best way to do so is through physical exercise." Plato (427-347 BC) referred to medicine as a sister art to physical exercise while the noted ancient Greek physician Galen (129-217 AD) penned several essays on aerobic fitness and strengthening muscles. This article briefly reviews the beneficial effects of physical activity on cardiovascular diseases.

Keywords: exercise, cardiovascular disease, lifestyle changes, physical activity, good health

\section{Introduction}

Cardiovascular disease (CVD) is the leading cause of death for both men and women in the United States. According to the American Heart Association (AHA), by the year 2030 , the prevalence of cardiovascular disease is expected to increase by $9.9 \%$, and the prevalence of heart failure and stroke are expected to increase by approximately $25 \%$. It is estimated that this will raise the total direct cost for healthcare to $\$ 818$ billion and the total indirect cost due to lost productivity to $\$ 275$ billion. ${ }^{1}$ On the other side of the Atlantic, one in five Europeans die because of coronary heart disease before the age of $75 .^{2}$ However, the burden of cardiovascular disease is not limited to developed countries anymore. In 2005, of the 58 million deaths that occurred worldwide, almost $30 \%$ were due to CVD. ${ }^{3}$ This is three times more deaths than are caused by all infectious diseases including HIV/AIDS, tuberculosis, and malaria combined. ${ }^{4,5}$ Nearly $80 \%$ of these CVD-related deaths occur in lower middle income countries, and one half of these deaths occur in women. It is projected that CVD will be responsible for 25 million deaths worldwide in 2020 . CVD has truly become a global epidemic. ${ }^{6}$

\section{Discussion}

CVD is a largely preventable condition. Although several risk factors for CVD are non-modifiable (age, male gender, race, and family history), many others are amenable to intervention. These include elevated blood pressure, abnormal blood sugar, high cholesterol, smoking, obesity, a high fat and high calorie diet and excess stress. 
The AHA recommends that blood pressure be kept under 140/90, fasting blood sugar be less than $110 \mathrm{mg} / \mathrm{dL}$, lowdensity lipoprotein cholesterol stay below $100 \mathrm{mg} / \mathrm{dL}$, smoking be stopped, a body mass index of less than $25 \mathrm{~kg} / \mathrm{m}^{2}$ be maintained, and a heart healthy diet be eaten. Moderate alcohol intake (less than two drinks per day), and aspirin taken in low doses among high risk groups are also recommended for their cardiovascular benefits. Another modifiable behavior with major therapeutic implications is inactivity. The cardiovascular effects of leisure time physical activity are compelling. ${ }^{7,8}$ The AHA recommends that all Americans invest in at least 30 minutes a day of physical activity on most days of the week, given its substantial health benefits; however, most healthy adults remain sedentary and fail to get an adequate amount of physical activity. ${ }^{9}$

Inactivity or a sedentary lifestyle is associated with increased cardiovascular events and premature death. ${ }^{10}$ Sedentary behavior, measured by television viewing time, has been associated with adverse cardiovascular health, increased obesity, diabetes mellitus, cancer, and early death. ${ }^{11}$ A review of several studies has confirmed that prolonged total sedentary time (measured objectively via accelerometer) has a deleterious relationship with cardiovascular risk factors, disease, and mortality outcomes. ${ }^{12}$

On the other hand, health benefits of adequate physical activities like walking, swimming, cycling, or stair climbing are well documented. Regular exercise has been shown to reduce type 2 diabetes, ${ }^{13,14}$ some cancers, ${ }^{15,16}$ falls, ${ }^{17}$ osteoporotic fractures, ${ }^{18}$ and depression. ${ }^{19}$ Improvements in physical function ${ }^{20-22}$ and weight management ${ }^{23-26}$ have also been shown. There is also an increase in cognitive function, ${ }^{27,28}$ enhancement of the quality of life, ${ }^{29}$ and decrease in mortality. ${ }^{30,31}$

Several occupational studies have shown adequate physical activity also provides extensive cardiovascular benefits. ${ }^{32-37}$ Chair bound double-decker bus drivers in London have more coronary heart disease than mobile conductors working on the same buses. ${ }^{38}$ Postal workers delivering mail by foot similarly have lower incidence of coronary disease than their office based colleagues. ${ }^{39}$ Railroad workers and longshoremen have reduced incidence of coronary heart disease compared to those in less active occupations. ${ }^{40,41}$

Well conducted long term studies have also documented the cardiovascular beneficial effects of regular exercise. Leisure time exercise reduced cardiovascular mortality during a 16 year follow up of men with high risk of coronary heart disease in the MRFIT study. ${ }^{42}$ In the Honolulu Heart Study, elderly men walking more than 1.5 miles per day similarly reduced their risk of coronary disease. ${ }^{43}$ Walking was associated with cardio-protection in the Nurses' Health Study, ${ }^{44}$ and moderate activity in post-menopausal women was similarly associated with a reduced risk of coronary disease in the Iowa Study. ${ }^{4}$ People engaging in regular exercise have also demonstrated other CVD benefits such as decreased rate of strokes and improvement in erectile dysfunction. There is also a 3-year increase in lifespan in these groups. ${ }^{46}$

Regular physical activity helps reduce several cardiovascular risk factors including obesity, ${ }^{47,48}$ dyslipidemia, ${ }^{49,50}$ hypertension, ${ }^{51,52}$ metabolic syndrome, ${ }^{53}$ and diabetes mellitus. ${ }^{54,55}$ Among patients with established coronary disease, regular physical activity has also been found to help improve angina-free activity, ${ }^{56}$ prevent heart attacks, ${ }^{57}$ and result in decreased death rates. ${ }^{58}$ In patients with heart failure, exercise improves heart function and quality of life. ${ }^{59,60}$ It also improves walking distance in patients with peripheral artery disease. ${ }^{61}$ Supervised exercise programs such as cardiac rehabilitation in patients who have undergone percutaneous coronary interventions, heart valve surgery, have stable chronic heart failure, are transplantation candidates or recipients, or have peripheral arterial disease result in significant short and long term CVD benefits. ${ }^{62-64}$

In 1995, the Centers for Disease Control and the American College of Sports Medicine recommended that all Americans try to engage in at least 30 minutes of moderate intensity physical activity on most or preferably all days of the week. ${ }^{65}$ Therapeutic activity should incorporate a range of motion exercises, resistance training, as well as an aerobic workout. Aerobic exercise improves cardio-respiratory fitness and favorably modulates several CVD risk factors. Leisure related aerobic activities such as walking, hiking, and gardening are generally more enjoyable, making them more conducive for long term adherence. ${ }^{66}$ Mild to moderate resistance training may be achieved by weight lifting, weight bearing calisthenics, or other resistance exercises involving the major muscle groups. They recommend that $8-10$ exercises be performed on two non-consecutive days of the week, with 8-12 repetitions of each exercise terminated by volitional fatigue. These provide an effective method for improving muscular strength and endurance, attenuating the rate-pressure product and improving coronary risk factors. ${ }^{67,68}$ Range of motion and stretching exercises such as yoga reduce sympathetic activity and improve several other cardiovascular risk parameters. Together, they have salutary cardiovascular effects. Since data indicates that cardiovascular disease begins early in life, physical interventions such as regular exercise should be started early for maximal effect. ${ }^{69-72}$ 
It is critical that lifelong health promoting behaviors, such as physical exercise, be introduced to youngsters. The US Department of Health and Human Services for young people recommends that school students achieve a target of 60 minutes of daily exercise. ${ }^{73}$ This may be achieved via a mandated curriculum involving moderate to vigorous activity during $50 \%$ of the physical education class time. Transition from high school to college is associated with a steep decline in physical activity. In addition to renovating outdated facilities, universities can help by developing mandatory health curricula teaching fitness based courses. Provision of convenient and adequate exercise time as well as free or inexpensive college credits for documented workout periods can further enhance compliance. Time spent on leisure time physical activity decreases further with entry into the workforce. Free health club memberships and paid supervised exercise time could help promote a continuing exercise regimen. Government sponsored subsidies to employers incorporating such exercise programs can help decrease the anticipated future cardiovascular disease burden in this population.

General physicians can play an important role in counseling patients and promoting exercise. ${ }^{74,75}$ Although barriers such as lack of time, inadequate or no reimbursement of physicians, and patient non-compliance exist,${ }^{76}$ medical reviews support the effectiveness of physician counseling, both in the short term ${ }^{77,78}$ and long term. ${ }^{79}$ The good news is that the percentage of adults advised to exercise by physicians in the United States has increased from $22.6 \%$ in 2000 to $32.4 \%$ in $2010 .{ }^{80}$ Physician empowerment, with training sessions and adequate reimbursement for their services, and patient tailored interventions with written materials, reminders, and follow up visits will further increase this percentage.$^{81}$ We expect that this should also greatly enhance patient compliance and ensure long term adherence.

\section{Conclusion}

Sedentary lifestyle is an important cardiovascular risk factor. CVD has no geographic, socioeconomic, or gender boundaries. It is the leading cause of death in developing and developed countries. Risk factors for CVD are consistent throughout the world, and this includes lack of physical activity. Although the benefits of leisure time physical activity for reducing CVD are irrefutable, only one in three Americans meets the minimal recommendations for activity as outlined by the Centers for Disease Control, the American College of Sports Medicine, and the AHA. Physical activity is an easy, inexpensive, and effective way to avoid CVD, and the benefits accrue, irrespective of the age at which a person initiates an exercise program. Reduced CVD burden as a result of regular exercise will not only improve the quality of life, but will increase the lifespan for millions of humans worldwide. There will also be an economic benefit to all the countries in the world with a saving of billions of health related dollars.

\section{Acknowledgment}

Publication made possible by a financial grant from Apple Diagnostic Laboratory, New Jersey, USA.

\section{Disclosure}

The author reports no conflict of interest in this work.

\section{References}

1. Heidenreich PA, Trogdon JG, Khavjou OA, et al. Forecasting the future of cardiovascular disease in the United States: a policy statement from the American Heart Association. Circulation. 2011;123(8):933-944.

2. Peterson S, Peto V, Rayner M, et al. European Cardiovascular Disease Statistics 2005 Edn (December 12, 2007). http://www.heartstats.org/ uploads/documents\%5CPDF.pdf.

3. Gaziano TA. Economic burden and the cost-effectiveness of treatment of cardiovascular disease in Africa. Heart. 2008;94(2):140-144.

4. Cardiovascular Diseases [homepage on the Internet]. Geneva: World Health Organization; [updated 2009]. Available from: http://www.who. int/mediacentre/factsheets/fs317/en/index.html; http:/www.who.int/ cardiovascular_diseases/priorities/en/index.html.

5. Preventing chronic diseases: a vital investment [homepage on the Internet]. Geneva: World Health Organization; [updated 2005]. Available from: http://www.who.int/chp/chronic_disease_report/ contents/en/index.html.

6. Murray C, Lopez A. The Global Burden of Disease. Cambridge: Harvard University Press; 1996.

7. Wartburton DE, Nicol CW, Bredin SS. Health benefits of physical activity: the evidence. CMAJ. 2006;174(6):801-809.

8. Hamer M, Chida Y. Walking and primary prevention: a meta-analysis of prospective cohort studies. Br J Sports Med. 2008;42(4):238-243.

9. US physical activity statistics [homepage on the Internet]. Atlanta: Centers for Disease Control and Prevention. Available from: http:// apps.nccd.cdc.gov/PASurveillance/StateSumV.asp.

10. Held C, Iqbal R, Lear SA, et al. Physical activity levels, ownership of goods promoting sedentary behavior and risk of myocardial infarction: results of the INTERHEART study. Eur Heart J. 2012;33(4):452-466.

11. Wijndaele $\mathrm{K}$, Brage $\mathrm{S}$, Besson $\mathrm{H}$, et al. Television viewing time independently predicts all-cause and cardiovascular mortality. Int J Epidemiol. 2011;40(1):150-159.

12. Dunstan DW, Thorp AA, Healy GN. Prolonged sitting: is it a distinct coronary heart disease risk factor? Curr Opin Cardiol. Sep 2011;26(5):412-419.

13. Roumen C, Blaak EE, Corpeleijn E. Lifestyle intervention for prevention of diabetes: determinants of success for future implementation. Nutr Rev. 2009;67(3):132-146.

14. Orozco LJ, Buchleitner AM, Gimenez-Perez G, Roqué I Figuls M, Richter B, Mauricio D. Exercise or exercise and diet for preventing type 2 diabetes mellitus. Cochrane Database Syst Rev. 2008;16(3): CD003054.

15. Friedenreich CM, Cust AE. Physical activity and breast cancer risk: impact of timing, type and dose of activity and population subgroup effects. Br J Sports Med. 2008;42(8):636-647. 
16. Tardon A, Lee WJ, Delgado-Rodriguez M, et al. Leisure-time physical activity and lung cancer: a meta-analysis. Cancer Causes Control. 2005;16(4):389-397.

17. Sherrington C, Whitney JC, Lord SR, Herbert RD, Cumming RG, Close JC. Effective exercise for the prevention of falls: a systematic review and meta-analysis. J Am Geriatr Soc. 2008;56(12):2234-2243.

18. Moayyeri A. The association between physical activity and osteoporotic fractures: a review of the evidence and implications for future research. Ann Epidemiol. 2008;18(11):827-835.

19. Teychenne M, Ball K, Salmon J. Physical activity and likelihood of depression in adults: a review. Prev Med. 2008;46(5):397-411.

20. Manini TM, Pahor M. Physical activity and maintaining physical function in older adults. Br J Sports Med. Jan 2009;43(1):28-31. Epub October 16, 2008.

21. Mian OS, Baltzopoulos V, Minetti AE, Narici MV. The impact of physical training on locomotor function in older people. Sports Med. 2007;37(8):683-701.

22. Chin A Paw MJ, van Uffelen JG, Riphagen I, van Mechelen W. The functional effects of physical exercise training in frail older people: a systematic review. Sports Med. 2008;38(9):781-793.

23. Keller C, Records K, Ainsworth B, Permana P, Coonrod DV. Interventions for weight management in postpartum women. $J$ Obstet Gynecol Neonatal Nurs. Jan-Feb 2008;37(1):71-79.

24. Seo DC, Sa J. A meta-analysis of psycho-behavioral obesity interventions among US multiethnic and minority adults. Prev Med. 2008;47(6):573-582.

25. Shaw K, Gennat H, O'Rourke P, Del Mar C. Exercise for overweight or obesity. Cochrane Database Syst Rev. October 18, 2006;4:CD003817.

26. Ohkawara K, Tanaka S, Miyachi M, Ishikawa-Takata K, Tabata I. A dose-response relation between aerobic exercise and visceral fat reduction: systematic review of clinical trials. Int $J$ Obes (Lond). Dec 2007;31(12):1786-1797. Epub July 17, 2007.

27. Erickson KI, Kramer AF. Aerobic exercise effects on cognitive and neural plasticity in older adults. Br J Sports Med. 2009;43(1):22-24.

28. Liu-Ambrose T, Donaldson MG. Exercise and cognition in older adults: is there a role for resistance training programmes? Br J Sports Med. Jan 2009;43(1):25-27. Epub November 19, 2008.

29. Bize R, Johnson JA, Plotnikoff RC. Physical activity level and healthrelated quality of life in the general adult population: a systematic review. Prev Med. Dec 2007;45(6):401-415. Epub July 21, 2007.

30. Barengo NC, Hu G, Lakka TA, Pekkarinen H, Nissinen A, Tuomilehto J. Low physical activity as a predictor for total and cardiovascular disease mortality in middle-aged men and women in Finland. Eur Heart $J$. Dec 2004;25(24):2204-2211.

31. Bucksch J, Helmert U. Leisure time sports activity and allcause mortality in West Germany (1984-1998). J Public Health. 2004;12(6):351-358.

32. Yu S, Yarnell JW, Sweetnam PM, Murray L. What level of physical activity protects against premature cardiovascular death? The Caerphilly study. Heart. May 2003;89(5):502-506.

33. Andersen LB, Schnohr P, Schroll M, Hein HO. All-cause mortality associated with physical activity during leisure time, work, sports, and cycling to work. Arch Intern Med. June 12, 2000;160(11):1621-1628.

34. Fransson E, De Faire U, Ahlbom A, Reuterwall C, Hallqvist J, Alfredsson L. The risk of acute myocardial infarction: interactions of types of physical activity. Epidemiology. Sep 2004;15(5):573-582.

35. Stamatakis E, Hillsdon M, Primatesta P. Domestic physical activity in relationship to multiple CVD risk factors. Am J Prev Med. Apr 2007;32(4):320-327.

36. Fransson EI, Alfredsson LS, de Faire UH, Knutsson A, Westerholm PJ. Leisure time, occupational and household physical activity, and risk factors for cardiovascular disease in working men and women: the WOLF Study. Scand J Public Health. 2003;31(5):324-333.

37. Boreham CA, Kennedy RA, Murphy MH, Tully M, Wallace WF, Young I. Training effects of short bouts of stair climbing on cardiorespiratory fitness, blood lipids, and homocysteine in sedentary young women. Br J Sports Med. Sep 2005;39(9):590-593.
38. Morris JN, Heady JA, Raffle PA, Roberts CG, Parks JW. Coronary heart disease and physical activity of work. Lancet. 1953;265(6795): 1053-1057; contd.

39. Morris JN, Heady JA, Raffle PA, Roberts CG, Parks JW. Coronary heart disease and physical activity of work (part 2). Lancet. November 28, 1953;265(6796):1111-1120; concl.

40. Taylor HL, Klepetar E, Keys A, Parlin W, Blackburn H, Puchner T. Death rates among physically active and sedentary employees in the railroad industry. Am J Public Health Nations Health. Oct 1962;52:1697-1707.

41. Paffenbarger RS, Hale WE. Work activity and coronary heart mortality. N Engl J Med. March 13, 1975;292(11):545-550.

42. Leon AS, Myers MJ, Connett J. Leisure time physical activity and the 16-year risks of mortality from coronary heart disease and all-causes in the Multiple Risk Factor Intervention Trial (MRFIT). Int $J$ Sports Med. Jul 1997;18 Suppl 3:S208-S215.

43. Hakim AA, Curb JD, Petrovitch H, et al. Effects of walking on coronary heart disease in elderly men: the Honolulu Heart Program. Circulation. 1999;100(1):9-13.

44. Manson JE, Hu FB, Rich-Edwards JW, et al. A prospective study of walking as compared with vigorous exercise in the prevention of coronary heart disease in women. $N$ Engl J Med. 1999;341(9):650-658.

45. Kushi LH, Fee RM, Folsom AR, Mink PJ, Anderson KE, Sellers TA. Physical activity and mortality in postmenopausal women. JAMA. April 23-30, 1997;277(16):1287-1292.

46. Wen CP, Wai JP, Tsai MK, et al. Minimum amount of physical activity for reduced mortality and extended life expectancy: a prospective cohort study. Lancet. October 1, 2011;378(9798):1244-1253. Epub August 16, 2011.

47. Poirier P, Després JP. Exercise in weight management of obesity. Cardiol Clin. Aug 2001;19(3):459-470.

48. Miller WC, Koceja DM, Hamilton EJ. A meta-analysis of the past 25 years of weight loss research using diet, exercise or diet plus exercise intervention. Int J Obes Relat Metab Disord. Oct 1997;21(10):941-947.

49. Yoshida H, Ishikawa T, Suto M, et al. Effects of supervised aerobic exercise training on serum adiponectin and parameters of lipid and glucose metabolism in subjects with moderate dyslipidemia. JAtheroscler Thromb. November 27, 2010;17(11):1160-1166. Epub August 25, 2010.

50. Durstine JL, Grandjean PW, Davis PG, Ferguson MA, Alderson NL, DuBose KD. Blood lipid and lipoprotein adaptations to exercise: a quantitative analysis. Sports Med. 2001;31(15):1033-1062.

51. Hagberg JM, Park JJ, Brown MD. The role of exercise training in the treatment of hypertension: an update. Sports Med. Sep 2000;30(3): 193-206.

52. Pescatello LS, Franklin BA, Fagard R, Farquhar WB, Kelley GA, Ray CA. American College of Sports Medicine position stand. Exercise and hypertension. Med Sci Sports Exerc. Mar 2004;36(3): 533-553.

53. Tjonna AE, Lee SJ, Rognmo O, et al. Aerobic interval training versus continuous moderate exercise as a treatment for the metabolic syndrome: a pilot study. Circulation. July 22, 2008;118(4):346-354. Epub July 7, 2008.

54. Lampman RM, Schteingart DE. Effects of exercise training on glucose control, lipid metabolism, and insulin sensitivity in hypertriglyceridemia and non-insulin dependent diabetes mellitus. Med Sci Sports Exerc. Jun 1991;23(6):703-712.

55. Ivy JL. Role of exercise training in the prevention and treatment of insulin resistance and non-insulin-dependent diabetes mellitus. Sports Med. Nov 1997;24(5):321-336.

56. Clausen JP, Trap-Jensen J. Heart rate and arterial blood pressure during exercise in patients with angina pectoris. Effects of training and of nitroglycerin. Circulation. Mar 1976;53(3):436-442.

57. Physical Activity Guidelines Advisory Committee. Physical Activity Guidelines Advisory Committee Report, 2008. Washington (DC): US Department of Health and Human Services; 2008:683.

58. Myers J, Prakash M, Froelicher V, Do D, Partington S, Atwood JE. Exercise capacity and mortality among men referred for exercise testing. $N$ Engl J Med. March 14, 2002;346(11):793-801. 
59. Flynn KE, Pina IL, Whellan DJ, et al. Effects of exercise training on health status in patients with chronic heart failure: HF-ACTION randomized controlled trial. JAMA. April 8, 2009;301(14):1451-1459. Erratum in: JAMA. December 2, 2009;302(21):2322.

60. Demopoulous L, Bijou R, Fergus I, Jones M, Strom J, LeJemtel TH. Exercise training in patients with severe congestive heart failure: enhancing peak aerobic capacity while minimizing the increase in ventricular wall stress. J Am Coll Cardiol. March 1, 1997;29(3):597-603.

61. Leng GC, Fowler B, Ernst E. Exercise for intermittent claudication. Cochrane Database Syst Rev. 2000;2:CD000990.

62. Balady GJ, Williams MA, Ades PA, et al. Core components of cardiac rehabilitation/secondary prevention programs: 2007 update: a scientific statement from the American Heart Association Exercise, Cardiac Rehabilitation, and Prevention Committee, the Council on Clinical Cardiology; the Councils on Cardiovascular Nursing, Epidemiology and Prevention, and Nutrition, Physical Activity, and Metabolism; and the American Association of Cardiovascular and Pulmonary Rehabilitation. Circulation. May 22, 2007;115(20):2675-2682. Epub May 18, 2007.

63. Ades PA. Cardiac rehabilitation and secondary prevention of coronary heart disease. $N$ Engl J Med. September 20, 2001;345(12):892-902.

64. Wenger NK. Current status of cardiac rehabilitation. JAm Coll Cardiol. April 29, 2008;51(17):1619-1631.

65. Pate RR, Pratt M, Blair SN, et al. Physical activity and public health: a recommendation from the Centers for Disease Control and Prevention and the American College of Sports Medicine. JAMA. February 1, 1995;273(5): 402-407.

66. Dishman RK, Buckworth J. Increasing physical activity: a quantitative synthesis. Med Sci Sports Exerc. Jun 1996;28(6):706-719.

67. McCartney N, McKelvie RS, Martin J, Sale DG, MacDougall JD. Weight-training-induced attenuation of the circulatory response of older males to weight lifting. J Appl Physiol. Mar 1993;74(3):1056-1060.

68. Pollock ML, Franklin BA, Balady GJ, et al. AHA Science Advisory. Resistance exercise in individuals with and without cardiovascular disease: benefits, rationale, safety, and prescription: An advisory from the Committee on Exercise, Rehabilitation, and Prevention, Council on Clinical Cardiology, American Heart Association; Position paper endorsed by the American College of Sports Medicine. Circulation. 2000;101(7):828-833.

69. Baker JL, Olsen LW, Sorensen TI. Childhood body-mass index and the risk of coronary heart disease in adulthood. $N$ Engl J Med. December 6, 2007;357(23):2329-2337.
70. Bjorge T, Engeland A, Tverdal A, Smith GD. Body mass index in adolescence in relation to cause-specific mortality: a follow-up of 230,000 Norwegian adolescents. Am J Epidemiol. July 1, 2008;168(1): 30-37. Epub May 13, 2008.

71. Raitakari OT, Juonala M, Viikari JS. Obesity in childhood and vascular changes in adulthood: insights into the Cardiovascular Risk in Young Finns Study. Int J Obes (Lond). Sep 2005;29 Supp1 2:S101-S104.

72. Sakuragi S, Abhayaratna K, Gravenmaker KJ, et al. Influence of adiposity and physical activity on arterial stiffness in healthy children: the lifestyle of our kids study. Hypertension. Apr 2009;53(4):611-616. Epub March 9, 2009.

73. US Department of Health and Human Services. 2008 Physical Activity Guidelines for Americans. Washington, DC: US Dept of Health and Human Services; 2008.

74. Walsh JM, Swangard DM, Davis T, McPhee SJ. Exercise counseling by primary care physicians in the era of managed care. Am J Prev Med. May 1999;16(4):307-313.

75. Glasgow RE, Eakin EG, Fisher EB, Bacak SJ, Brownson RC. Physician advice and support for physical activity: results from a national survey. Am J Prev Med. 2001;21(3):189-196.

76. Abramson S, Stein J, Schaufele M, Frates E, Rogan S. Personal exercise habits and counseling practices of primary care physicians: a national survey. Clin J Sport Med. Jan 2000;10(1):40-48.

77. Jacobson DM, Strohecker L, Compton MT, Katz DL. Physical activity counseling in the adult primary care setting: position statement of the American College of Preventive Medicine. Am J Prev Med. Aug 2005;29(2):158-162.

78. Eakin EG, Glasgow RE, Riley KM. Review of primary care-based physical activity intervention studies: effectiveness and implications for practice and future research. J Fam Pract. Feb 2000;49(2):158-168.

79. Writing Group for the Activity Counseling Trial (ACT) Research Group. Effects of physical activity counseling in primary care: the Activity Counseling Trial: a randomized controlled trial. JAMA. 2001;286(6):677-687.

80. Barnes PM, Schoenborn CA. Trends in adults receiving a recommendation for exercise or other physical activity from a physician or other health professional. NCHS Data Brief. Feb 20;86:1-8.

81. Jacobson DM, Strohecker L, Compton MT, Katz DL. Physical activity counseling in the adult primary care setting: position statement of the American College of Preventive Medicine. Am J Prev Med. Aug 2005;29(2):158-162.
International Journal of General Medicine

\section{Publish your work in this journal}

The International Journal of General Medicine is an international peer-reviewed open-access journal that focuses on general and internal medicine, pathogenesis, epidemiology, diagnosis, monitoring and treatment protocols. The journal is characterized by the rapid reporting of reviews, original research and clinical studies across all disease areas.

\section{Dovepress}

A key focus is the elucidation of disease processes and management protocols resulting in improved outcomes for the patient. The manuscript management system is completely online and includes a very quick and fair peer-review system. Visit http://www.dovepress.com/ testimonials.php to read real quotes from published authors. 